\title{
Corporate Governance and Firm Performance: The Case of Sugar Sector of Pakistan
}

\author{
Faisal Rasheed \\ School of Business, University of Central Punjab, Pakistan \\ faisal.rasheed7786@gmail.com \\ Sehrish Safdar \\ School of Business, University of Central Punjab, Pakistan \\ seri7374@gmail.com
}

\begin{abstract}
The following paper focuses on the Sugar industry of Pakistan and the impact of different corporate administration mechanisms on the performance of the firms operating in the industry. The paper collects data from a five year period of 2010-2015 regarding the corporate administration mechanisms of 15 listed sugar mills of the country. The paper uses different methodological tests and methods of estimation to understand the impact. As per the results, it can be evidently witnessed that the impact of corporate administration mechanisms like Chairman Duality, and board on the performance of the firms is insignificant. As only the data for a limited number of companies in the sugar mills exist, the study analyses the data of around 15 companies for a period of five to six years to understand the significant impact of corporate administration on the performance of firms.
\end{abstract}

Keywords: corporate, performance, administration, governance

\section{Introduction}

Governing the corporate entities is known as corporate administration and it includes all the businesses and not just the company. The main focus of corporate administration is one the profits of the business and not on the wealth of the organizations. Furthermore, the interests of the stakeholders are protected by corporate administration from expropriation. Enhancing the performance of firms, good corporate administration plays an important role in the economic stability of the country and access to outside capital is increased. Hence, a public policy objective is served by corporate administration. There are different objectives that can be achieved with good corporate administration like reducing the cost of transaction and capital costs, and reducing the vulnerability of the financial crisis. Corporate administration is also concerned with the relationship between board of directors, management, monitoring shareholders, controlling shareholders and other stakeholders. However, no one definition of corporate administration is applicable in all the situations. The many different corporate administration definitions that exist today are highly dependent on the author and the institution, along with the legal tradition and the country.

It has been highlighted by different authors that the set of mechanisms that ensure that the outsiders are safeguarded against insiders' expropriation is known as corporate administration. They further clarify that the insiders include both controlling shareholders and managers. Another group of authors highlight that the affairs of the corporate body that are directed and controlled by the set of mechanisms in order to protect and serve the interests of all the stakeholders is considered to be corporate administration. Corporate administration have many different mechanisms like code of conduct, management techniques, rules, image building risk

The current issue and full text archive of this journal is available at www.jraspublications.org/index.php/JRAS/issue/archive

Journal of Research in Administrative Sciences (JRAS)

VII(II), 32-34, ISSN: 2664-2433 management strategy and the laws that effect the affairs and directions of any organization directly. These sets of mechanisms are also the tools that come into play when protecting the interests of the stakeholders and the individuals.

Sugar was heavily focused on and the government focused on improving the sugar industry. In 1961, the first sugar mill was established in Sindh and by 1998, there were around 75 sugar mills operating in the country. These sugar mills collectively produced around 2.4 million metric ton sugar. Today, the sugar cane industry is the $2^{\text {nd }}$ largest agro industry in Pakistan after textile and an important cash and industrial crop In Pakistan. In the world, Pakistan is $60^{\text {th }}$ largest country in sugar yield, $15^{\text {th }}$ largest sugar producer, and area under sugar cultivation is $5^{\text {th }}$ largest. In Sindh, KPK and Punjab, there are around 83 sugar mills. The sugarcane industry of Pakistan is produces many other by-products like bagasse in paper and press mud and alcohol used by the pharmaceutical sector.

\section{Literature Review}

Ponnu suspects (2008), that the effect of duality CEO and the reach of free Heads for the analysts who carry out the organization came closer consideration in business management. If it came too late, then there would be no critical connection between the Duality and autonomy board to organize the execution. Javid et al. (2008) in its audit claimed that the corporate administration has positive impact and a notable role in firm performance. Ujunwa (2012) through the use of information board relapse demonstrate that the unit Board size, chairman and director of duality were in contrast to the solid execution, although autonomy board has positive effect on the fixed version. Company management and board ask principle of the organization's hypothesis, management hypothesis and assertion 
hypothesis. Cheng Wu et al. (2005) concluded that the CEO duality is adversely and generally identified with sound execution. Lam et al. (2012) inspected that the board was decided Sythese (negatively)

identified with the resistant design. Such a positive or negative relationship is based on the autonomy or non-freedom of the board's organization. The President and the duality of the President are identified with a solid execution on the contrary. Steiner (1996) et al. That the choice of property, the property rights of the corresponding sessions, the available and potential owners of the distributed organization. This is a question of coordination are coordinated in the potential owners with special qualities with companies that have their own characteristics. Hart, (1995) also indicated that the titular attributes include access to data, capital and learning and fixed qualities indicated, predicts the monetary hypothesis of the company's ownership of the property to be distributed, to reduce exchange costs. However, little sense of the true ownership of the determinants has tangible results for the qualities and behavior of the company. Better corporate administration is associated with improved work as can be seen in the case-valuation exposures and, as shown by some comments about the country's output. By Wei et al. (2010) has reduced the control limit on large sheets in total successively. The audit found that risk management makes an organization to reduce the first experience of risk, for example, the support is likely to be related to a significant risk of avoidance, for example, the extent of recognition of shareholders.

In a review by Shleifer et al. (1996) demonstrated that business management is the assertion of money managers for the hypothesis of the authorities. This makes the feel of the certainty of researchers and banks based on cash management standards. In this way organizations in Pakistan have to choose the most important decisions that remember the true objective, to focus on a specific goal. So Pakistan has to face the possibility of good business management for progress in solidarity. Pakistan's associations must strengthen in the global marketplace and bring out trusted theorists as shareholders or joint venture partners.

Mak et al. (2001) portray that the administration has a tendency to be less effort in the investigation of its companies. Guarantees of responsibility and control of the transfer in the light of the administration of the weaker cash certify that the organization and continue to require less probably copies the main impulse that will be responsible for obtaining such solid bureaucratic organizations. Be that as it may, the negative association between the State and a solid execution must not be united. The creators showed a preliminary investigation that the course of the relationship in the country under study is based. Ronald et al. Study (2000), regardless of whether the corporate structure is the same, or especially separated between organizations. They have also left no refinement in the management structure of the company with the fiasco in pulses that are associated with development, from data 1984-1985. We used the OLS true relapse technique to expand the piece of enterprise management structure in the decision to grow. Despite the fact that the organizations did not differentiate between selfsufficient, undiminished sales execution and CEO, as did the rise of more external gourmet experts in single-line efforts. As for the driven organization, we confirm that CEOs bring compensation for the execution and storage of cut associations. It has found no strong demand that has within the misleading management relationship with the alternative having any effect

As by Coleman et al. (2006), size of the board decided identifies with ROA, for most contradictory identified with rate of development of bid of execution factors. Jones et al. (1982), which are clearly shown in their exploration of articles that organizations that have different ownership and control, obligation for characterization and change in corporate qualities regularly management is left sufficient. The union with the basic partners could be disguised as having spoken as unofficial people to the Board. People can talk successfully with different meetings of property (example, family foundations, large square owner or institutional investors and owner). In a few nations or government employees are qualified for the board position. However, owners may also intentionally nominate individuals with connections to partner grapes that are fixed for development or survival is essential. Levine (2004) highlights two audit reports that when possession and control dissent, Irreconcilables amongst supervisors and shareholders. What is key for the organization, then, is to find ways to deal with shed these cases, that is, find compelling instruments of corporate administration. Jensen et al. (1976) uncover office costs of this sort and expect that a chief who claims something under $100 \%$ of the rest of the income benefits of the firm has potential hopeless conditions with the outside shareholders. Regulatory possession can change the energy between the two individual petitioner gatherings and along these lines bring down office costs inside the organization. The model of the association between authoritative ownership and hierarchical costs is direct, and the perfect point for the organization is accomplished when the supervisors get the most shares of the organization. In the low levels of regulatory proprietorship, managerial possession alters the interests of administrators and outside shareholders by decreasing the propelling authoritative powers for expanded use, the utilization of little endeavors, and sense of duty regarding non-upgrading firms.

\section{Methodology}

Taking the sugar mill industry into consideration, there are around 83 organizations operating in Pakistan. The following paper highlights a methodological analysis for 15 companies and these were chosen as the sample for research. The annual reports of the companies of Pakistan for the period of 2010-2015 was taken to get the data on ROA, board composition, board size and duality. Analysis of the Basic Balance Sheet issued by the State Bank of Pakistan was taken for the calculation of ROA.

As per Himmelberg (1999), a panel data approach is useful to remove the unobservable heterogeneity that exists between organizations and that is used for this research also. This data approach method also combines the cross section observation panel and the time series and that is its major advantage. Another advantage of panel data approach as per Yasser (2001) is that the biasness is minimized which may result due to separate firm level data that are separated in different aggregates. Another essential benefit of having the panel data approach is that the unobservable effects in pure time series or cross section data can also be measured by this method. The main purpose of this research methodology is to evaluate and understand the impact that corporate administration has on the performance of firms in the large sugar sector of Pakistan. The model for this study is as follows.

ROA $=\alpha+\beta_{1}(B S)+\beta_{2}(B C)+\beta_{3}($ Duality $)+\varepsilon$

Where: $\mathrm{ROA}=$ Return on Asset

BS=Board Size

$\mathrm{BC}=$ Board Composition

Duality $=\mathrm{CEO}$ and Chairman Duality

$\varepsilon=$ Error

Following are the Dependent Variables for the study: ROA

Following are the independent variables for the study: Duality, Size, BCom

Interpretation

\begin{tabular}{|c|c|c|c|}
\hline & N & Mean & Std. Deviation \\
\hline Size & 72 & 26.25 & 13.960 \\
\hline Bcom & 72 & 20.83 & 8.681 \\
\hline Duality & 72 & .42 & .496 \\
\hline ROA & 72 & 6.25 & 14.274 \\
\hline Valid N (list wise) & 72 & & \\
\hline
\end{tabular}

The results have shown that the board size, medium structure board and duality, free variables, 26.25, 20.83 and 0.42 are individually. The standard deviation is 13,960 per Board share, 8,681 for the 
board-creation and the standard deviation of the duality is 0.496 . Then, the average value of the variable is ROA (return on assets) 6.2514 .274 and standard deviation of resource yield.

Table 2. ANOVA ${ }^{b}$

\begin{tabular}{|l|c|c|c|c|c|}
\hline \multirow{2}{*}{ Model } & $\begin{array}{c}\text { Sum of } \\
\text { Squares }\end{array}$ & $\mathrm{df}$ & $\begin{array}{c}\text { Mean } \\
\text { Square }\end{array}$ & F & Sig. \\
\hline \multirow{2}{*}{$\begin{array}{c}1 \text { Regression } \\
\text { Residual }\end{array}$} & 3480.350 & 3 & 1160.117 & 7.642 & $.000 \mathrm{a}$ \\
\cline { 2 - 7 } & 10322.619 & 68 & 151.803 & & \\
\cline { 2 - 7 } & 13802.969 & 71 & & & \\
\hline
\end{tabular}

Table 3: Model Summary

\begin{tabular}{|c|c|c|c|c|}
\hline $\begin{array}{c}\text { Mode } \\
1\end{array}$ & $\mathrm{R}^{\prime}$ & R Square & $\begin{array}{c}\text { Adjusted } \\
\text { R }\end{array}$ & $\begin{array}{l}\text { Std. Error of } \\
\text { the Estimate }\end{array}$ \\
\hline
\end{tabular}

a) Predictors: (Constant), duality, size, comp

The consequences of Table 2 show that all autonomous factors have an exceptionally large impact on ROA. Since it is critical in Oton what the CEO / President duality shows a noticeable effect in the fixed version shows all things as a measure of the board, the composition of the board. The consequences of Table 3 show the safety coefficient estimate, which is $25.6 \%$. This means that the $25.6 \%$ change in ROA is due to advances in the management components of the company. The consequences of Table 3 show that the plate estimate has some influence on ROA. Since it is critical for 0.032 , which shows that it significantly affects the fixed version. The one-time change in plate size receives the ROA change from 0245. These results are in agreement with. The plaque piece has a consistent effect on the fixed version, which is measured by ROA. The Governing Body of the Organization does not have a significant effect on the fixed version. It is clarified that if more executives feel free on the board diminishes the performance of the company. In this way, organizations use the parts of the self-employed executives do not complete. Bosses can sit on the board to satisfy Board agreements or to prove that the board is "stand-alone", but in reality it is not CEO / President influenced dual ROA is fundamental at 0.007, which shows that CEO / President Duality Deteriorates sturdy construction. Tcal for board size, board composition and CEO / President Duality are independent of 2,189, 0.375 and 2,784. This implies, in family businesses when the chairman's and director's seat is carried out by the same individual performance companies expand these results.

\section{Conclusion}

A global issue today is corporate administration and the impact of corporate administration with regards to different sectors is calculated by different authors. In 2002, the first corporate administration code of Pakistan was issued by the Securities and Exchange Commission of the country. SECP built a settlement in the management of the company in 2004. This test carried out to evaluate the impact of enterprise management for the solid implementation in Pakistan. For this reason we have selected the sugar segment in Pakistan to bring the corporate administration effect into the fixed version. Corporate administration measures by ROA. As the results show that corporate administration has critical implications for the fixed version. Measure table has a noticeable effect on the fixed version, the composition of the board of insignificant influence ROA and CEO / President influenced dual ROA. In addition, all autonomous factors as a whole have a notable effect on corporate administration. There are some limitations for this study also. In this study, only 15 companies could be chosen for analysis as only limited data for these organizations exist, despite a total 84 companies operating in the sugar mills of Pakistan. The major limitation for the study was that the data for many other companies was not available. There are many recommendations that can be followed. Firstly, the code of corporate administration as highlighted by Pakistan's Securities and Exchange Commission must be followed. An optimal board size can be integrated like a limit of seven directors on board. Furthermore, it is important that the board should have both non-executive and executive directors. Lastly, the chair of the chairman, president or CEO must be separate.

\section{References}

i. Abidin, kamal, Jusoff, 2011, "Board Structure and Corporate Performance in Malaysia". International Journal of Economics and Finance. Annual Reports Issued by the Companies.

ii. Biekpe, "The Relationship between Board Size, Board Composition, CEO Duality and Firm Performance: Experience from Ghana."

iii. Cheng Wu, Chiang Lin, cheng, Feng Lai, "The Effects of Corporate Governance on Firm Performance".

iv. Dar, Naseem, Rehman, Niazi, 2011, "Corporate Governance and Firm Performance a Case Study of Pakistan Oil and

v. Gas Companies Listed in Karachi Stock Exchange". Global Journal of Management and Business Research.

vi. Friday, Godwin, Paul, 2011, "Board composition and Corporate Performance: An analysis of Evidence from Nigeria”. Research Journal of Finance and Accounting.

vii. Ibrahim, Rehman, Raoof, 2010, "Role of Corporate Governance in Firm Performance: A Comparative Study between

viii. Chemical and Pharmaceutical Sectors of Pakistan". International Research Journal of Finance and Economics.

ix. Javid, Iqbal, 2008, "Does Corporate Governance Affect a Firm's Performance? A Case Study Pakistani Market." NUST Journal of Business and Economics.

x. Lam, T. Y., \& Lee, S. K. (2012). Family ownership, board committees and firm performance: evidence from Hong Kong. Corporate Governance, 12(3), 6-6.

xi. Mollah, S., Al Farooque, O., \& Karim, W. (2012). Ownership structure, corporate governance and firm performance: Evidence from an African emerging market. Studies in Economics and Finance, 29(4), 301-319.

xii. Mir, Nishat, 2004, "Corporate Governance Structure and Firm Performance in Pakistan - An Empirical Study". Ponnu, 2008, "Corporate Governance Structures and the Performance of Malaysian Public Listed Companies." International Review of Business Research Papers.

xiii. Sunday O, 2008, "Corporate Governance and Firm Performance: The Case of Nigerian Listed Firms". European

xiv. Ujunwa, A. (2012). Board Characteristics and the Financial Performance of Nigerian Quoted Firms. Corporate Governance, 12(5), 5-5.

xv. Yasser, 2011, "Corporate governance and performance: An Analysis of Pakistani listed firms." International Research Journal of Library, Information and Archival Studies.

xvi. Yasser, Entebang, Mansor, 2011, "Corporate governance and firm performance in Pakistan: The case of Karachi

xvii. Stock Exchange (KSE)-30”. Journal of Economics and International Finance Journal of Economics, Finance and Administrative Sciences. 